\title{
KINERJA GURU IPS PASCASERTIFIKASI PENDIDIK DALAM MELAKSANAKAN PEMBELAJARAN PADA TINGKAT SMP DI KOTA MAKASSAR
}

\author{
Shasliani Syamsul, Aman \\ Program Pascasarjana Pendidikan IPS, Universitas Negeri Yogyakarta \\ sitishasliani@gmail.com, aman@uny.ac.id
}

\begin{abstract}
Abstrak
Penelitian ini bertujuan untuk mengetahui kinerja guru IPS SMP pascasertifikasi Kota Makassar dilihat dari aspek perencanaan, pelaksanaan dan penilaian pembelajaran, serta untuk mengetahui perbedaan kinerja guru pascasertifikasi di Kota Makasar dilihat dari lama waktu setelah sertifikasi. Penelitian ini merupakan penelitian kuantitatif deskriptif. Sampel penelitian 6 kepala sekolah, 27 guru, dan 130 siswa. Pengumpulan data menggunakan kuesioner. Teknik analisis menggunakan analisis deskriptif. Hasil penelitian ini menunjukkann bahwa Guru IPS tingkat SMP pascasertifikasi di Kota Makassar memiliki kinerja yang baik dilihat dari aspek perencanaan pembelajaran, yang ditunjukkan dengan nilai rerata sebesar 4,04. Guru IPS pascasertifikasi memiliki kinerja yang baik dilihat dari aspek pelaksanaan pembelajaran, yang ditunjukkan dengan nilai rerata sebesar 3,77. Guru IPS pascasertifikasi memiliki kinerja yang baik dilihat dari aspek penilaian pembelajaran, yang ditunjukkan dengan nilai rerata sebesar 3,96. Kinerja guru pascasertifikasi lebih dari lima tahun dengan guru pascasertifikasi lima tahun kurang secara signifikan tidak memiliki perbedaan.
\end{abstract}

Kata kunci: kinerja guru, sertifikasi, pelaksanaan pembelajaran

\section{PERFORMANCE OF SOCIAL SCIENCE TEACHER AFTER CERTIFICATION TO IMPLEMENTATION LEARNING LEVEL JUNIOR HIGH SCHOOL IN MAKASSAR CITY}

\author{
Shasliani Syamsul, Aman \\ Program Pascasarjana Pendidikan IPS, Universitas Negeri Yogyakarta \\ sitishasliani@gmail.com,aman@uny.ac.id
}

\begin{abstract}
This study aims to determine the performance of junior high school social studies teacher post-certification Makassar City viewed from the aspect of planning, implementation and assessment of learning, and to investigate differences in teacher performance post-certification in Makasar seen from a long time after certification. This research is quantitative descriptive. The research sample 6 principals, 27 teachers and 130 students. Collecting data using questionnaires. Mechanical analysis using descriptive analysis. The results of this study has pointed out that the Master IPS junior level after certification in Makassar has a good performance from the aspects of the learning plan, which indicated an average value of 4.04. After certification social studies teacher has a good performance from the aspects of the implementation of learning, which is shown to an average value of 3.77. After certification social studies teacher has a good performance from the aspects of learning assessment, which indicated an average value of 3.96. Post-certification of teachers' performance over five years with teacher certification after five years was significantly less no difference.
\end{abstract}

Keywords: teahcer performance, certification, implementation learning 


\section{Pendahuluan}

Guru memegang peran utama dalam pendidikan, khususnya pendidikan yang diselenggarakan secara formal di sekolah/madrasah. Guru merupakan komponen yang paling berpengaruh terhadap terciptanya proses dan hasil pendidikan yang berkualitas. Oleh karena itu, upaya perbaikan apapun yang dilakukan untuk meningkatkan kualitas pendidikan tidak akan memberikan sumbangan yang signifikan tanpa didukung oleh guru yang profesional dan berkualitas.

Menurut Undang-undang Nomor 14 Tahun 2005 tentang Guru dan Dosen Pasal 1 (Depdiknas, 2005), guru didefinisikan sebagai "pendidik profesional dengan tugas utama mendidik, mengajar, membimbing, mengarahkan, melatih, menilai dan mengevaluasi peserta didik. Tugas guru sebagai profesi meliputi mendidik, mengajar dan melatih. Mendidik berarti meneruskan dan mengembangkan nilai-nilai hidup.

Guru harus bisa menjadi guru yang inspiratif selalu mengikuti perkembangan dan senantiasa mengembangkan pengetahuan yang dimilikinya yang nantinya akan disampaikan kepada peserta didiknya disamping mengajar sesuai dengan kurikulum, hal ini dilakukan agar peserta didik mempunyai pengetahuan yang lebih luas. Berbagai cara yang bisa dilakukan oleh para guru agar dapat meningkatkan profesionalismenya salah satunya dengan menempuh program sertifikasi guru. Sertifikasi adalah proses pemberian sertifikat pendidik untuk guru dan dosen. Tujuan sertfikasi adalah untuk menentukan kelayakan guru dalam melaksanakan tugas sebagai agen pembelajaran, meningkatkan profesionalisme guru, meningkatkan proses dan hasil pendidikan dan mempercepat terwujudnya tujuan pendidikan nasional. Program sertifikasi bagi guru ditempuh melalui dua jalur yaitu penilaian portofolio dan jalur pendidikan.

Sertifikasi guru tidak hanya bertujuan untuk mendapat sertifikat pendidik saja namun dengan adanya sertifikasi diharapkan kinerja guru menjadi lebih baik dan tujuan Pendidikan Nasional tercapai dengan baik. Guru yang telah disertifikasi diharapkan bisa menjadi guru yang profesional, bisa mengajar dengan baik, bisa mengembangkan ilmu pengetahuan yang dimilikinya dalam melaksanakan proses pembelajaran di kelas.
Pembelajaran merupakan proses interaksi peserta didik dengan pendidik dan sumber belajar pada suatu lingkungan belajar (Undang-undang Nomor 20 tahun 2003). Proses pembelajaran dapat berjalan baik apabila terdapat hubungan timbal balik antara guru dengan siswanya. Guru bertanya siswa menjawab, guru menerangkan siswa mendengarkan. Sumber belajar yang digunakan membantu guru dalam menyampaikan bahan ajar kepada siswa. Guru memerlukan suatu kemampuan atau kompetensi untuk dapat menyampaikan bahan ajar tersebut sehingga siswa dapat menerima dan memahaminya dengan baik.

Kompetensi merupakan seperangkat pengetahuan, keterampilan, dan perilaku yang harus dimiliki, dihayati dan dikuasai oleh guru atau dosen dalam melaksanakan tugas keprofesionalannya (UU No. 14 tahun 2005 tentang Guru dan Dosen) (Depdiknas, 2005). Seorang guru harus memiliki pengetahuan dan keterampilan yang lebih untuk diajarkan kepada siswanya. Selain itu, guru juga seharusnya memiliki perilaku atau kepribadian yang baik yang dapat dicontoh dan ditiru oleh siswanya. Kompetensi ini wajib dimiliki oleh guru agar kegiatan pembelajaran di kelas dapat berjalan dengan kondusif dan siswa dapat menerima serta mengimplementasikan apa yang telah dipelajarinya dalam kehidupan sehari-hari.

Seorang guru harus memiliki kualifikasi minimum dan sertifikasi sesuai dengan jenjang kewenangan mengajar seperti yang tercantum dalam Undang-undang Nomor 20 tahun 2003 tentang Sistem Pendidikan Nasional Pasal 42 ayat (1). Hal ini diperkuat dengan UU Nomor 14 Tahun 2005 tentang Guru dan Dosen Pasal 8 (Depdiknas, 2005) yang mewajibkan guru untuk memiliki kualifikasi akademik, kompetensi, sertifikat pendidik, sehat jasmani dan rohani, serta memiliki kemampuan untuk mewujudkan tujuan pendidikan nasional. Kompetensi guru yang dimaksud dalam pasal 8 tersebut yaitu kompetensi pedagogik, kompetensi kepribadian, kompetensi social dan kompetensi profesional. Dengan demikian, keempat kompetensi tersebut dapat menunjukkan kinerja guru dalam proses pembelajaran.

Proses pembelajaran yang dilaksanakan oleh guru dilaksanakan berdasarkan beberapa tahap, yaitu perencanaan, pelaksanaan dan evaluasi. Kegiatan perencanaan pembel- 
ajaran dapat dilakukan dengan pengembangan silabus dan penyusunan rencana pelaksanaan pembelajaran. Pelaksanaan pembelajaran merupakan implementasi atau praktik dari kegiatan belajar mengajar yang terdiri atas kegiatan pembukaan, kegiatan inti, dan kegiatan penutup. Evaluasi yaitu kegiatan untuk menilai jalannya kegiatan pembelajaran dan menilai ketercapaian tujuan pembelajaran. Oleh karena itu, kinerja guru dapat dilihat melalui ketiga kegiatan tersebut.

Kinerja guru tidak hanya dapat dinilai oleh kepala sekolah ataupun pengawas, tetapi siswa juga dapat menilai kinerja guru berdasarkan apa yang dilihat dan dirasakan oleh siswa di kelas selama proses pembelajaran berlangsung. Siswa dapat menilai kinerja gurunya dengan melihat bagaimana cara guru tersebut mengajar. Berdasarkan cara mengajar guru tersebut dapat diketahui apakah kemampuan atau kompetensi yang dimiliki guru tersebut baik atau tidak.

Kemampuan atau kompetensi guru dalam mengajar dapat ditingkatkan dengan mengikuti program sertifikasi guru yang diselenggarakan oleh pemerintah. Guru yang telah mengikuti program sertifikasi tersebut akan mendapat sertifikat pendidik yang merupakan bentuk pengakuan pemerintah atas keprofesionalan guru. Guru yang telah bersertifikasi seharusnya memiliki kinerja yang lebih baik dibanding dengan guru yang belum bersertifikasi. Guru bersertifikasi dituntut untuk terus mengembangkan kinerjanya baik itu dengan mengikuti berbagai pelatihan dan pendidikan yang diselenggarakan oleh pemerintah, maupun dengan melakukan penelitian yang berguna untuk meningkatkan kompetensi dan kinerjanya.

Berdasarkan berita yang ditulis oleh Dariyanto (2015) diketahui bahwa masih ada guru di Indonesia yang belum berpendidikan hingga S1 atau D4, yaitu sebesar $40 \%$. Hal ini tidak sesuai dengan UU Nomor 14 tahun 2005 tentang Guru dan Dosen Pasal 9 (Depdiknas, 2005) yang menyebutkan bahwa seorang guru harus berpendidikan minimal S1 atau D4. Selain itu, guru yang belum bersertifikat pendidik diketahui berjumlah sekitar $45 \%$. Hal ini didukung oleh data hasil rakernas Lembaga Perguruan Tenaga Kependidikan Swasta Indonesia (LPTKSI) bahwa dari total 2.791.204 guru, yang bersertifikasi dan S1 1.250.791 orang (Direktorat Jenderal Pendidikan Islam
Kemenag RI, 2011). Sisanya 1.540.403 guru belum berpendidikan S1. Hal ini menunjukkan bahwa guru di Indonesia yang layak mengajar masih mi-nim dan belum memenuhi persyaratan sebagai pendidik profesional seperti yang telah dite-tapkan pemerintah melalui undang-undang.

Selain itu, jika dilihat dari ketersediaan sarana, pemerintah belum mendistribusikannya secara merata. Masih ada sekolah yang belum memiliki sarana, seperti LCD beserta layar proyektornya, yang dapat memudahkan guru dalam menyampaikan materi pelajaran. Ada pula sekolah yang hanya memiliki LCD proyektor saja, sehingga penampilan gambar menjadi tidak maksimal karena dilakukan di dinding kelas atau papan tulis. Selain itu, tidak semua guru dapat mengoperasikannya dengan baik. Hal ini disebabkan guru tidak dapat mengoperasikan sarana yang disediakan sekolah dengan baik, seperti komputer dan LCD proyektor. Dengan demikian, kegiatan pembelajaran menjadi terhambat dan waktu banyak yang terbuang karena guru terlalu sibuk untuk dapat mengoperasikannya.

Makassar merupakan salah satu kota yang kualitas pendidikannya merosot. Wakil Ketua DPRD Kota Makassar juga menyampaikan bahwa kualitas pendidikan di Makassar yang semakin merosot ini diakibatkan oleh lemahnya monitoring dan pengawasan yang dilakukan oleh pemerintah Kota Pengamat pendidikan Sulawesi Selatan, Adi Suriadi Culla membenarkan kondisi yang menimpa dunia pendidikan saat ini (Yusran, 2013). Menurutnya pemberian tunjangan sertifikasi guru tidak membuat kinerja mereka semakin meningkat, malah banyak guru yang semaumaunya masuk di kelas dan menyerahkan pekerjaanya kepada tenaga honorer, tanpa ada pendampingan. Hal tersebut berlaku bagi semua guru mata pelajaran termasuk IPS. Indrawati (2013, p. 2) menyebutkan bahwa kinerja guru IPS di SMP N 4 Singaraja, khususnya dalam kompetensi pedagogik, belum dilaksanakan sesuai dengan standar kurikulum yang ditetapkan dan tidak memanfaatkan teknologi pembelajaran sedangkan kinerja guru IPS bersertifikasi profesi dalam penguasaan kompetensi profesional sesudah sertifikasi berdasarkan penilaian kepala sekolah berada pada kriteria sangat tinggi, menurut guru sejawat berada pada kriteria sangat tinggi dan 
menurut penilaian siswa berada pada kriteria sangat tinggi (Suryarahman \& Hastuti, 2014, p. 140).

Berdasarkan permasalahan tersebut, perlu dilakukan penelitian mengenai kinerja guru pascasertifikasi. Penelitian dilakukaan untuk mengetahui kinerja guru setelah mendapat sertifikat pendidik yang dilihat dalam proses pembelajaran. Proses belajar mengajar guru yang dapat mencerminkan kinerja seorang guru yaitu pada perencanaan, pelaksanaan, dan evaluasi pembelajaran (Rusman, 2013 , p. 76). Kinerja guru dinilai oleh kepala sekolah dalam kegiatan supervisi. Namun, kinerja guru juga dapat dinilai oleh dirinya sendiri, rekan sejawat serta siswa yang diajar oleh guru yang bersangkutan. Penilaian diri dinilai lebih menunjukkan kelemahan pelaksanaan pembelajaran dinilai lebih mencerminkan kinerja guru karena pada kegiatan ini kemampuan guru yang sesungguhnya dalam mengajar lebih terlihat dibanding pada kegiatan perencanaan dan evaluasi pembelajaran. Pelaksanaan pembelajaran dapat dinilai oleh siswa, guru dan kepala sekolah.

Kinerja merupakan suatu wujud perilaku seseorang atau organisasi dengan orientasi prestasi (Direktorat Tenaga Kependidikan, 2008, p. 20). Definisi tersebut menjelaskan bahwa kinerja merupakan suatu bentuk prestasi/hasil yang dicapai seseorang atau sekelompok orang terhadap perilaku/pekerjaan yang telah dilakukan. Kinerja guru merupakan tingkat keberhasilan yang ditunjukkan oleh kemampuan guru dalam melaksanakan tugas atau perannya sebagai pendidik (Ningsih, 2013 , p. 3). Pengertian tersebut menjelaskan bahwa kinerja guru merupakan tingkat keberhasilan yang dicapai guru sebagai tenaga pendidik.

Proses belajar mengajar guru yang dapat mencerminkan kinerja seorang guru yaitu pada perencanaan, pelaksanaan, dan evaluasi pembelajaran (Rusman, 2013, p. 76). Kinerja guru dinilai oleh kepala sekolah dalam kegiatan supervisi. Namun, kinerja guru juga dapat dinilai oleh dirinya sendiri, rekan sejawat serta siswa yang diajar oleh guru yang bersangkutan. Penilaian diri sendiri dinilai lebih menunjukkan kelemahan pelaksanaan pembelajaran dinilai lebih mencerminkan kinerja guru karena pada kegiatan ini kemampuan guru yang sesungguhnya dalam mengajar lebih terlihat dibanding pada kegiatan peren- canaan dan evaluasi pembelajaran. Pelaksanaan pembelajaran dapat dinilai oleh siswa, guru dan kepala sekolah.

Kinerja guru dalam melaksanakan kegiatan pembelajaran dapat dinilai dari kemampuannya dalam mengelola kelas, menggunakan media dan sumber belajar, serta metode yang digunakan. Pengelolaan kelas menunjukkan kemampuan guru dalam menciptakan suasana yang kondusif di dalam kelas. Penggunaan media dan sumber belajar menunjukkan kemampuan guru dalam memanfaatkan berbagai bahan/media yang ada disekitar sekolah untuk belajar. Penggunaan metode menunjukkan bahwa guru dapat menyampaikan materi dengan berbagai macam cara/metode yang sesuai dengan bahan yang diajarkan. Metode pembelajaran yang digunakan guru selama ini hanya menggunakan ceramah untuk menyampaikan materi pembelajaran (Rahayu, 2015). Metode pembelajaran yang hanya menggunakan ceramah dalam penyampaian materi dapat menyebabkan siswa lebih mudah bosan dan mengantuk saat pembelajaran berlangsung. Hal ini dikarenakan siswa hanya memperhatikan dan mendengarkan penjelasan dari guru. Oleh karena itu, guru seharusnya menguasai berbagai metode pembelajaran yang dapat diaplikasikan dalam kegiatan pembelajaran.

Kinerja guru dalam pelaksanaan pembelajaran dapat dilihat pula dalam kemampuannya melakukan penilaian pembelajaran. Taras (2005, p. 466) menjelaskan bahwa penelitian merujuk pada keputusan yang dapat dibenarkan sesuai dengan tujuan yang hendak dicapai, serta dapat melihat perbandingan dan peringkat seseorang. (William, 2012, p. 15). Menjelaskan bahwa penilaian pembelajaran merupakan salah satu cara yang dianggap paling ampuh untuk meningkatkan prestasi belajar siswa.

Ingweson (2000, p. 39) menjelaskan bagaimana cara mengajar dan mengelola kelas yang baik agar dapat meningkatkan motivasi siswa yaitu dengan membuat pembelajaran menjadi lebih menantang, menarik, dan melibatkan media pembelajaran seperti komputer atau yang tersedia di sekolah serta sumber belajar. Araujo \& Slomski (2013, p. 21) menjelaksan bahwa metode pembelajaran digunakan untuk mencapai akhir pembelajaran. Akhir pembelajaran yang baik dapat diperoleh dengan proses pembelajaran yang benar. 
Proses pembelajaran yang benar dapat dicapai dengan penggunakan/pemilihan metode pembelajaran yang tepat.

Carpenter (2006, p. 19) dalam penelitiannya menjelaskan bahwa siswa lebih memilih untuk aktif dalam proses pembelajarannya, sehingga metode pembelajaran yang digunakan merupakan metode pembelajaran yang aktif dan dikolaborasi dengan metode pembelajaran yang lain.

Pecheone \& Chung (2006, p. 23) menjelaskan bahwa penilaian terhadap kinerja guru mencakup praktik pembelajaran atau proses kegiatan belajar mengajar yang dilakukan. Hasil penilaian tersebut memiliki potensi untuk memberikan evaluasi yang sebenarnya. Artinya, penilaian kinerja guru berdasarkan pelaksanaan pembelajaran di kelas dapat menunjukkan hasil dari kinerja guru yang sesungguhnya, karena kemampuan guru yang sebenarnya dapat terlihat ketika guru sedang melaksanakan kegiatan belajar mengajar di kelas.

Crown Darling-Hammond (2010, p. 5) menjelaskan bahwa tujuan dilakukannya penilaian adalah untuk mengetahui apakah guru yang merupakan lulusan pendidikan telah mengembangkan keterampilan mengajarnya di kelas menjadi lebih efektif atau belum. Seseorang yang merupakan lulusan pendidikan memang sudah dibekali oleh keterampilanketerampilan untuk menjadi guru yang baik, seperti cara mengajar, mengelola kelas, menggunakan media pembelajaran dan sebagainya. Namun, kemampuan tersebut harus terus dikembangkan mengikuti perkembangan kurikulum yang digunakan dan perkembangan jaman. Selain itu, hasil tes siswa dapat digunakan untuk mengukur kinerja guru, namun hasil tersebut belum dapat mengukur dan menggambarkan kinerja guru saat proses pembelajaran berlangsung.

Aguinis (Elliott, 2015, p. 102), penilaian kinerja merupakan proses yang berkelanjutan yang digunakan untuk mengidentifikasi, mengukur dan mengembangkan kinerja individu sesuai dengan tujuan. Ontario (2010, p. 5) menjelaskan bahwa penilaian kinerja guru adalah bagian dari kesinambungan pembelajaran profesional. Pembelajaran profesional mendukung kegiatan pembelajaran dan praktik penilaian yang efektif dengan membangun dan melengkapi pembelajaran sebelumnya, sehingga terdapat perbaikan pada pembelajaran berikutnya. Oleh karena itu pembelajar- an oleh guru diperoleh sepanjang karirnya dalam mengajar. Gallant \& Mayer (2012, p. 296) menjelaskan bahwa penilaian kinerja guru merupakan portofolio terstruktur. Portofolio tersebut merupakan bentuk penilaian yang dilakukan oleh guru yang bersangkutan untuk mendokumentasikan kegiatan pembelajarannya, pengetahuan dan hasil belajar siswa.

Kemampuan/kompetensi dapat ditingkatkan dengan memberikan pelatihan atau dengan mengikutsertakan guru dalam program sertifikasi yang diselenggarakan oleh pemerintah. Guru yang telah lulus sertifikasi akan mendapatkan tunjangan sebagai bentuk apresiasi dan motivasi kepada guru untuk terus dapat meningkatkan kinerjanya sebagai pendidik. Darling-Hammond \& Youngs (2002, p. 16) menjelaskan bahwa sertifikasi dapat diperoleh guru apabila guru tersebut telah memenuhi beberapa syarat. Syarat-syarat tersebut yaitu keterampilan dasar dan kemampuan umum akademik, pengetahuan mengenai materi pelajaran, pengetahuan mengenai pengajaran dan pembelajaran, serta pengalaman mengajar. Boyd, Goldhaber, Lankford, \& Wyckoff (2007, p. 46) menyampaikan bahwa sertifikat pendidik harus mengikuti ujian khusus yang diselenggarakan oleh pihak yang berwenang. Sebelum mengikut ujian, guru diharuskan untuk mengikuti pelatihan/kursus serta praktik mengajar terlebih dahulu. Pelatihan dan praktik tersebut meliputi penguasaan kompetensi. Setelah mengikuti pelatihan dan praktik mengajar, guru dapat mengikuti ujian kompetensi. Wahyudi, Supranoto, \& Suji (2012, p. 161) menjelaskan bahwa kinerja program sertifikasi guru memiliki nilai yang positif terhadap peningkatan kualitas guru. Hal tersebut berarti bahwa guru yang telah mengikuti program sertifikasi menunjukkan kinerja yang lebih baik. Guru yang telah lulus sertifikasi akan mendapatkan tunjangan sebagai bentuk apresiasi dan motivasi kepada guru untuk terus dapat meningkatkan kinerja-nya sebagai pendidik.

Menurut Depdiknas (Direktorat Tenaga Kependidikan, 2008, p. 22) indikator penilaian kinerja guru dilakukan melalui tiga kegiatan, yaitu perencanaan program kegiatan pembelajaran, pelaksanaan kegiatan pembelajaran, dan evaluasi/penilaian pembelajaran. Pada tahap perencanaan, guru dalam kegiatan pembelajaran adalah tahap yang akan berhubungan dengan kemampuan guru menguasai 
bahan ajar (Rusman, 2013, p. 75). Kemampuan guru ini dapat lihat dari cara atau proses penyusunan program kegiatan pembelajaran yang dilakukan oleh guru, yaitu pengembangan silabus dan rencana pelaksanaan pembelajaran. Penilaian terhadap pelaksanaan pembelajaran dapat dilihat dari kemampuan guru dalam mengelola kelas, kemampuan dalam menggunakan dan memanfaatkan media dan sumber belajar, serta kemampuan dalam menggunakan berbagai metode pembelajaran. Aspek penilaian kinerja guru dapat dilihat dari teknik evaluasi yang diterapkan, menilai siswa secara adil dan objektif, serta memberikan feedback terhadap tugas yang dikerjakan siswa.

Berdasarkan uraian tersebut, peneliti berkeinginan untuk meneliti tentang kinerja guru pascasertifikasi pendidik. Oleh karena itu, peneliti melakukan penelitian dengan judul "Kinerja Guru IPS Pascasertifikasi Pendidik dalam Melaksanakan Pembelajaran pada Tingkat SMP di Kota Makassar".

\section{Metode Penelitian}

Penelitian ini merupakan kuantitatif dengan menggunakan metode deskriptif. karena penelitian ini menggunakan angkaangka dalam pengumpulan data sampai pada penyajian hasil penelitian. Metode deskriptif merupakan penelitian yang digunakan untuk menggambarkan suatu fenomena dengan membandingkan satu variabel atau lebih, pada dua atau lebih sampel yang berbeda, atau pada waktu yang berbeda (Sugiyono, 2011, p. 36). Penelitian ini bertujuan untuk mengetahui kinerja guru IPS Pascasertifikasi Pendidik dalam pelaksanaan pembelajaran.

Penelitian ini dilaksanakan di Kota Makassar, Sulawesi Selatan. Penelitian dilaksanakan pada bulan Februari - Maret 2016. Populasi dalam penelitian ini yaitu seluruh guru IPS yang telah bersertifikat pendidik tingkat SMP di Kota Makassar sebanyak 168 orang, yang tersebar di 112 sekolah negeri dan swasta. Sampel dipilih dengan menggunakan metode puposive sampling, yaitu 6 kepala sekolah, 27 guru IPS, dan 130 siswa SMP.

Penelitian ini dilakukan dengan menyusun proposal dan instrumen penelitian. Berdasarkan proposal dan instrumen tersebut, kemudian dilakukan pengambilan data di lapangan. Data diperoleh langsung dari respon- den penelitian, yaitu kepala sekolah, guru IPS, dan siswa SMP se-Kota Makassar. Data yang telah diperoleh dengan instrumen kemudian diolah dan hasilnya disajikan dalam bentuk tabel sehingga lebih mudah untuk dipahami. Hasil analisis kemudian dibandingkan dengan kriteria keberhasilan penelitian, yaitu:

\section{Perencanaan Pembelajaran}

Kemampuan guru dapat lihat dari cara atau proses penyusunan program kegiatan pembelajaran yang dilakukan oleh guru. Perencanaan pembelajaran dikatakan baik apabila (Rusman, 2013, p. 75): (a) Guru dapat mengembangkan silabus dengan baik, (b) Guru dapat menyusun rencana pelaksanaan pembelajaran dengan baik.

\section{Pelaksanaan Pembelajaran}

Pelaksanaan pembelajaran dikatakan baik jika (Rusman, 2013, p. 76): (a) Guru dapat mengelola kelas sehingga siswa dapat mengikuti pembelajaran dengan baik, (b) Guru memanfaatkan media dan sumber belajar yang tersedia di lingkungan sekitar secara efektif, (c) Guru menerapkan metode pembelajaran yang bervariasi sesuai dengan materi yang diajarkan dan kondisi siswa di kelas.

\section{Penilaian Hasil Belajar}

Penilaian hasil belajar dikatakan efektif jika (Kemdikbud, 2015, p. 5): (a) Guru menerapkan berbagai teknik penilaian yang efektif, (b) Guru menilai hasil belajar siswa secara objektif dan adil, (c) Guru memberikan feedback terhadap tugas-tugas yang dikerjakan siswa.

Data penelitian dikumpulkan dengan menggunakan instrumen pengumpulan data. Instrumen pengumpulan data merupakan alat yang digunakan untuk mengumpulkan data berdasarkan teknik yang digunakan. Teknik pengumpulan data dalam penelitian ini menggunakan kuesioner/angket. Kuesioner merupakan sejumlah pertanyaan/pernyataan tertulis yang digunakan untuk memperoleh informasi dari responden dalam arti laporan tentang pribadinya, atau hal-hal yang diketahui (Arikunto, 2010, p. 194).

Teknik analisis data yang digunakan dalam penelitian ini yaitu analisis deskriptif dan inferensial. Analisis ini berguna untuk menggambarkan/mendeskripsikan kinerja gu- 
ru yang dapat dilihat dari nilai-rata-rata, standar deviasi, nilai maksimum dan minimum, perhitungan persentase kinerja guru IPS pascasertifikasi tingkat SMP di Kota Makassar berdasarkan penilaian diri sendiri, kepala sekolah dan siswa. Hasil analisis disajikan dalam bentuk tabel dan kemudian ditentukan kinerja guru masuk dalam kategori mana. Berikut kategori rerata skor.

Tabel 1. Kategori Rerata Skor

\begin{tabular}{cc}
\hline Rerata Skor & Kategori \\
\hline$\leq 1,80$ & Tidak Baik \\
$1,81-2,60$ & Kurang Baik \\
$2,61-3,40$ & Cukup Baik \\
$3,41-4,20$ & Baik \\
$>4,20$ & Sangat Baik \\
\hline
\end{tabular}

Sumber: (Widoyoko, 2009, p. 238)

Analisis inferensial digunakan untuk mengetahui perbedaan kinerja guru pascasertifikasi berdasarkan lama sertifikasi pada tingkat SMP se-Kota Makassar, yaitu lima tahun setelah sertifikasi dan lima tahun $\mathrm{ku}$ rang. Perbedaan kinerja guru dapat dilihat dari nilai rerata yang diperoleh dari ketiga aspek penilaian, yaitu aspek perencanaan pembelajaran, aspek pelaksanaan pembelajaran dan penilaian pembelajaran. Jika nilai rerata yang diperoleh guru sertifikasi lebih dari lima tahun lebih besar dari guru pascasertifikasi kurang dari lima tahun maka kinerja guru pascasertifikasi mengalami peningkatan. Namun, jika nilai rerata yang diperoleh guru sertifikasi lebih dari lima tahun lebih kecil atau sama dengan guru pascasertifikasi kurang dari lima tahun maka kinerja guru pascasertifikasi tidak mengalami peningkatan.

\section{Hasil Penelitian dan Pembahasan}

Penelitian ini dilakukan di enam sekolah tingkat SMP di Kota Makassar Sulawesi Selatan dengan Kepala Sekolah, Guru IPS dan Siswa yang menjadi responden untuk menilai kinerja guru IPS. Aspek yang dinilai dalam kinerja guru pada penelitian ini yaitu perencanaan pembelajaran, pelaksanaan pembelajaran, dan penilaian pembelajaran. Sekolah yang menjadi sampel dalam penelitian ini yaitu SMP Muhammadiyah 12 Makassar, SMP Muhammadiyah 14 Makassar, SMP N 27 Makassar, SMP N 2 Makassar, SMP N 13 Makassar, dan SMP N 8 Makassar.
Tabel 2. Hasil Penilaian Kepala Sekolah, Guru dan Siswa terhadap Kinerja Guru IPS SMP di Kota Makassar

\begin{tabular}{lcccc}
\hline Aspek yang & \multicolumn{3}{c}{ Penilai } & Rerata \\
\cline { 2 - 4 } Dinilai & Kepsek & Guru & Siswa & Skor \\
\hline Perencanaa & 3,67 & 4,42 & & 4,04 \\
Pelaksanaan & 3,60 & 4,16 & 3,56 & 3,77 \\
Penilaian & 3,86 & 4,19 & 3,84 & 3,96 \\
\hline Rerata Skor & 3,71 & 4,25 & 3,70 & 3,89 \\
\hline
\end{tabular}

Tabel 2 menunjukkan bahwa hasil penilaian yang dilakukan oleh Kepala Sekolah, Guru dan Siswa memiliki rerata skor sebesar 3,89. Nilai tersebut masuk dalam kategori "Baik" karena nilai yang diperoleh berada di antara 3,41-4,20. Rerata skor penilaian yang dilakukan oleh kepala sekolah terhadap kinerja guru IPS sebesar 3,71 atau pada kategori "Baik" karena nilai yang diperoleh berada di antara 3,41-4,20. Rerata skor penilaian yang dilakukan oleh guru IPS terhadap kinerjanya sebesar 4,25 atau pada kategori "Sangat Baik" karena nilai yang diperoleh berada di antara > 4,20. Rerata skor penilaian yang dilakukan oleh siswa terhadap kinerja guru IPS sebesar 3,70 atau pada kategori "Baik" karena berada di antara nilai 3,41-4,20. Hal ini tidak jauh berbeda dengan temuan Suryarahman \& Hastuti (2014, p. 140) yang menyatakan bahwa kinerja guru IPS bersertifikasi profesi dalam penguasaan kompetensi pedagogik, kompetensi kepribadian, dan kompetensi sosial setelah sertifikasi di Kabupaten Lombok Utara berdasarkan penilaian kepala sekolah, guru sejawat, dan siswa berada pada kriteria sangat tinggi.

Jika dilihat dari tiap aspek, rerata skor pada perencanaan pembelajaran sebesar 4,04 atau pada kategori "Baik" karena nilai yang diperoleh berada di antara 3,41-4,20. Kinerja guru pada aspek perencanaan pembelajaran dikatakan baik karena secara keseluruhan guru telah dapat mengembangkan silabus dan menyusun RPP dengan baik serta sesuai dengan standar kompetensi, kompetensi dasar dan indikator yang harus dimiliki siswa. Rerata skor pada aspek pelaksanaan pembelajaran sebesar 3,77 atau pada kategori "Baik" karena nilai yang diperoleh berada di antara 3,41-4,20. Kinerja guru pada aspek pelaksanaan pembelajaran dikatakan baik karena secara keseluruhan guru telah dapat mengelola kelas dengan baik, memanfaatkan media dan sumber belajar secara efektif, serta menerapkan metode pembelajaran sesuai dengan standar 
kompetensi, kompetensi dasar dan indikator yang harus dimiliki siswa. Rerata skor pada aspek penilaian pembelajaran sebesar 3,96 atau pada kategori "Baik" karena nilai yang diperoleh berada di antara 3,41-4,20. Kinerja guru pada aspek penilaian pembelajaran dikatakan baik karena secara keseluruhan guru telah menerapkan berbagai teknik penilaian yang efektif, melakukan penilaian secara objektif dan adil, serta memberikan feedback terhadap tugas-tugas yang dikerjakan siswa. Dengan demikian, dapat disimpulkan bahwa guru IPS SMP di Kota Makassar memiliki kinerja yang baik. Berikut disajikan hasil penilaian kinerja guru IPS tiap sekolah.

\section{Penilaian Kinerja Guru IPS di SMP Muhammadiyah 12 Makassar}

Hasil penelitian di lapangan terhadap satu orang Kepala Sekolah, satu orang Guru IPS dan 21 orang siswa di SMP Muhammadiyah 12 Makassar, diperoleh tingkat kinerja guru IPS SMP sebagai berikut.

Tabel 3. Hasil Penilaian Kepala Sekolah, Guru dan Siswa terhadap Kinerja Guru IPS SMP Muhammadiyah 12 Makassar

\begin{tabular}{lcccc}
\hline \multirow{2}{*}{$\begin{array}{c}\text { Aspek yang } \\
\text { Dinilai }\end{array}$} & \multicolumn{3}{c}{ Penilai } & \multirow{2}{*}{$\begin{array}{c}\text { Rerata } \\
\text { Skor }\end{array}$} \\
\cline { 2 - 4 } & Kepsek & Guru & Siswa & \\
\hline Perencanaa & 3,43 & 3,86 & & 3,64 \\
Pelaksanaan & 3,58 & 2,78 & 3,10 & 3,15 \\
Penilaian & 4,00 & 2,44 & 3,18 & 3,21 \\
\hline Rerata Skor & 3,67 & 3,03 & 3,14 & 3,28 \\
\hline
\end{tabular}

Tabel 3 menunjukkan bahwa hasil penilaian yang dilakukan oleh Kepala Sekolah, Guru dan Siswa memiliki rerata skor sebesar 3,28. Nilai tersebut masuk dalam kategori "Cukup Baik" karena berada di antara nilai 2,61-3,40. Rerata skor penilaian yang dilakukan oleh kepala sekolah terhadap kinerja guru IPS sebesar 3,67 atau pada kategori "Baik" karena berada di antara nilai 3,414,20. Rerata skor penilaian yang dilakukan oleh guru IPS terhadap kinerjanya sebesar 3,03 atau pada kategori "Cukup Baik" karena berada di antara nilai 2,61-3,40. Rerata skor penilaian yang dilakukan oleh siswa terhadap kinerja guru IPS sebesar 3,14 atau pada kategori "Cukup Baik" karena berada di antara nilai 2,61-3,40. Kinerja guru dikatakan "Cukup
Baik" karena berdasarkan penilaian kepala sekolah, guru dan siswa secara keseluruhan kegiatan perencanaan pembelajaran, pelaksanaan dan penilaian pembelajaran telah dilaksanakan meskipun masih terdapat guru yang belum memiliki kinerja yang baik, serta skor rerata yang diperoleh berada di antara 2,613,40 di mana nilai tersebut termasuk dalam kategori cukup baik.

Jika dilihat dari tiap aspek, rerata skor pada perencanaan pembelajaran sebesar 3,64 atau pada kategori "Baik" karena berada di antara nilai 3,41-4,20. Hal tersebut menunjukkan bahwa pada aspek perencanaan pembelajaran ini guru memiliki kinerja yang baik. Guru memiliki kemampuan dalam pengembangan silabus dengan baik. Guru memiliki kemampuan penyusunan rencana pelaksanaan pembelajaran dengan baik. Rerata skor pada aspek pelaksanaan pembelajaran sebesar 3,15 atau pada kategori "Cukup Baik" karena berada di antara nilai 2,61-3,40. Hal tersebut menunjukkan bahwa pada aspek pelaksanaan pembelajaran ini guru memiliki kinerja yang cukup baik. Guru memiliki kemampuan yang baik dalam mengelola kelas. Guru terkadang menggunakan media pembelajaran saat mengajar. Selain itu, guru juga tidak pernah membuat sumber belajar sendiri yang dinilai lebih efektif dibanding buku paket (seperti modul) dan tidak pernah mengajak siswa untuk membuat media pembelajaran sendiri, sehingga siswa menjadi lebih pasif. Namun metode yang digunakan kurang variatif. Guru jarang mengkombinasikan beberapa metode dalam pelaksanaan pembelajaran sehingga siswa akan kesulitan menerima materi pelajaran jika metode yang digunakan tidak tepat.Rerata skor pada aspek penilaian pembelajaran sebesar 3,21 atau pada kategori "Cukup Baik" karena berada di antara nilai 2,61-3,40. Hal tersebut menunjukkan bahwa pada aspek penilaian pembelajaran ini guru memiliki kinerja yang cukup baik. Guru memiliki kemampuan dalam menerapkan teknik penilaian namun teknik yang diterapkan belum variatif atau sering menggunakan teknik yang sama, serta jarang melakukan penilaian disetiap akhir pertemuan. Guru menilai hasil belajar siswa dengan objektif dan adil, yaitu tidak dengan membede-bedakan siswa yang satu dengan siswa yang lain. guru terkadang memberikan feedback terhadap setiap tugas-tugas yang dikerjakan siswa, seperti memberi komentar tentang 
pekerjaan siswa, memberikan refleksi disetiap akhir pertemuan, dan membahas hasil pekerjaan siswa di depan kelas. Dengan demikian dapat disimpulkan bahwa kinerja guru IPS pascasertifikasi pada aspek pelaksanaan dapat dikatakan belum baik karena belum memenuhi indikator keberhasilan yang ditetapkan.

\section{Penilaian Kinerja Guru IPS di SMP}

Muhammadiyah 14 Makassar

Hasil penelitian di lapangan terhadap satu orang Kepala Sekolah, satu orang Guru IPS dan enam orang siswa di SMP Muhammadiyah 14 Makassar, diperoleh tingkat kinerja guru IPS SMP seperti pada Tabel 4.

Tabel 4. Hasil Penilaian Kepala Sekolah, Guru dan Siswa terhadap Kinerja Guru IPS SMP Muhammadiyah 14 Makassar

\begin{tabular}{lcccc}
\hline Aspek yang & \multicolumn{3}{c}{ Penilai } & Rerata \\
\cline { 2 - 4 } Dinilai & Kepsek & Guru & Siswa & Skor \\
\hline Perencanaa & 2,71 & 4,00 & & 3,36 \\
Pelaksanaan & 2,00 & 4,06 & 2,50 & 2,85 \\
Penilaian & 2,43 & 4,33 & 3,02 & 3,26 \\
\hline Rerata Skor & 2,38 & 4,13 & 2,76 & 3,09 \\
\hline
\end{tabular}

Berdasarkan Tabel 4 menunjukkan bahwa hasil penilaian yang dilakukan oleh Kepala Sekolah, Guru dan Siswa memiliki rerata skor sebesar 3,09. Nilai tersebut masuk dalam kategori "Cukup Baik" karena berada di antara nilai 2,61-3,40. Rerata skor penilaian yang dilakukan oleh kepala sekolah terhadap kinerja guru IPS sebesar 2,38 atau pada kategori "Kurang" karena berada di antara nilai 1,81-2,60. Rerata skor penilaian yang dilakukan oleh guru IPS terhadap kinerjanya sebesar 4,13 atau pada kategori "Baik" karena berada di antara nilai 3,41-4,20. Rerata skor penilaian yang dilakukan oleh siswa terhadap kinerja guru IPS sebesar 2,76 atau pada kategori "Cukup Baik" karena berada di antara nilai 2,61-3,40. Kinerja guru dikatakan "Cukup Baik" karena berdasarkan penilaian kepala sekolah, guru dan siswa secara keseluruhan kegiatan perencanaan pembelajaran, pelaksanaan dan penilaian pembelajaran telah dilaksanakan namun masih terdapat guru yang belum memiliki kinerja yang baik.

Jika dilihat dari tiap aspek, rerata skor pada perencanaan pembelajaran sebesar 3,36 atau pada kategori "Cukup Baik" karena berada di antara nilai 2,61-3,40. Hal tersebut menunjukkan bahwa pada aspek perencanaan pembelajaran ini guru memiliki kinerja yang baik. Guru memiliki kemampuan dalam pengembangan silabus dengan cukup baik. Rerata skor pada aspek pelaksanaan pembelajaran sebesar 2,85 atau pada kategori "Cukup Baik" karena berada di antara nilai 2,61-3,40. Hal tersebut menunjukkan bahwa pada aspek pelaksanaan pembelajaran ini guru memiliki kinerja yang cukup baik. Guru memiliki kemampuan dalam mengelola kelas namun masih tergolong Cukup Baik karena guru jarang memberi kesempatan kepada siswa untuk mengemukakan pendapat sehingga siswa menjadi kurang aktif dalam pembelajaran. Guru masih belum memiliki kemampuan dalam menggunakan media dan sumber belajar dengan baik, seperti jarang memanfaatkan media pembelajaran yang tersedia di lingkungan sekolah. Guru memiliki kemampuan dalam menggunakan metode pembelajaran namun metode yang digunakan kurang variatif. Guru jarang menggunakan metode tanya jawab dalam kegiatan pembelajaran.

Rerata skor pada aspek penilaian pembelajaran sebesar 3,26 atau pada kategori "Cukup Baik" karena berada di antara nilai 2,61-3,40. Hal tersebut menunjukkan bahwa pada aspek penilaian pembelajaran ini guru memiliki kinerja yang cukup baik. Guru memiliki kemampuan dalam menerapkan teknik penilaian namun teknik yang diterapkan belum variatif atau sering menggunakan teknik yang sama, serta kadang memberikan penilaian di akhir pertemuan. Guru memiliki kemampuan menilai hasil belajar siswa dengan objektif dan adil. Guru jarang memberikan feedback terhadap tugas-tugas yang dikerjakan siswa, seperti memberi komentar tentang pekerjaan siswa, memberikan refleksi di akhir pertemuan, dan membahas hasil pekerjaan siswa di depan kelas. Dengan demikian dapat disimpulkan bahwa kinerja guru IPS pascasertifikasi pada aspek pelaksanaan dapat dikatakan belum baik karena belum memenuhi indikator keberhasilan yang ditetapkan.

\section{Penilaian Kinerja Guru IPS di SMP N 27 Makassar}

Hasil penelitian di lapangan terhadap satu orang Kepala Sekolah, lima orang Guru IPS dan 28 orang siswa di SMP Negeri 27 Makassar, diperoleh tingkat kinerja guru IPS SMP sebagai berikut. 
Tabel 5. Hasil Penilaian Kepala Sekolah, Guru dan Siswa terhadap Kinerja Guru IPS SMP N 27 Makassar

\begin{tabular}{lcccc}
\hline Aspek yang & \multicolumn{3}{c}{ Penilai } & Rerata \\
\cline { 2 - 4 } \multicolumn{1}{c}{ Dinilai } & Kepsek & Guru & Siswa & Skor \\
\hline Perencanaa & 3.86 & 4.51 & & 4.19 \\
Pelaksanaan & 3.58 & 4.04 & 3.53 & 3.72 \\
Penilaian & 3.43 & 4.13 & 3.83 & 3.80 \\
\hline Rerata Skor & 3.62 & 4.23 & 3.68 & 3.84 \\
\hline
\end{tabular}

Tabel 5 menunjukkan bahwa hasil penilaian yang dilakukan oleh Kepala Sekolah, Guru dan Siswa memiliki rerata skor sebesar 3,84. Nilai tersebut masuk dalam kategori "Baik" karena berada di antara nilai 3,41-4,20. Rerata skor penilaian yang dilakukan oleh kepala sekolah terhadap kinerja guru IPS sebesar 3,62 atau pada kategori "Baik" karena berada di antara nilai 3,41-4,20. Rerata skor penilaian yang dilakukan oleh guru IPS terhadap kinerjanya sebesar 4,23 atau pada kategori "Sangat Baik" karena nilai yang diperoleh lebih besar dari 4,20 . Rerata skor penilaian yang dilakukan oleh siswa terhadap kinerja guru IPS sebesar 3,68 atau pada kategori "Baik" karena berada di antara nilai 3,41-4,20. Kinerja guru dikatakan "Baik" karena berdasarkan penilaian kepala sekolah, guru dan siswa secara keseluruhan kegiatan perencanaan pembelajaran, pelaksanaan dan penilaian pembelajaran telah dilaksanakan dengan baik dan memenuhi kriteria keberhasilan, serta mendapat skor rerata lebih dari 3,41 di mana nilai tersebut termasuk dalam kategori baik.

Jika dilihat dari tiap aspek, rerata skor pada perencanaan pembelajaran sebesar 4,19 atau pada kategori "Baik" karena nilai yang diperoleh lebih besar dari 3,41-4,20. Hal tersebut menunjukkan bahwa pada aspek perencanaan pembelajaran ini guru memiliki kinerja yang sangat baik. Guru memiliki kemampuan dalam pengembangan silabus dengan sangat baik. Guru memiliki kemampuan penyusunan rencana pelaksanaan pembelajaran dengan baik. Rerata skor pada aspek pelaksanaan pembelajaran sebesar 3,72 atau "Baik" karena berada di antara nilai 3,41-4,20. Hal tersebut menunjukkan bahwa pada aspek pelaksanaan pembelajaran ini guru memiliki kinerja yang baik. Guru memiliki kemampuan dalam mengelola kelas. Guru memiliki kemampuan dalam menggunakan media dan sumber belajar dengan cukup baik. Guru me- miliki kemampuan dalam menggunakan metode pembelajaran. Rerata skor pada aspek penilaian pembelajaran sebesar 3,80 atau "Baik" karena berada di antara nilai 3,41-4,20. Hal tersebut menunjukkan bahwa pada aspek penilaian pembelajaran ini guru memiliki kinerja yang baik. Guru memiliki kemampuan dalam menerapkan teknik penilaian yang variatif. Guru memiliki kemampuan menilai hasil belajar siswa dengan objektif dan adil. Guru memberikan feedback terhadap tugas-tugas yang dikerjakan siswa, seperti memberi komentar tentang pekerjaan siswa, memberikan refleksi di akhir pertemuan, dan membahas hasil pekerjaan siswa di depan kelas. Dengan demikian dapat disimpulkan bahwa kinerja guru IPS pascasertifikasi pada aspek pelaksanaan dapat dikatakan baik karena telah memenuhi indikator keberhasilan yang ditetapkan.

\section{Penilaian Kinerja Guru IPS di SMP N 2 Makassar}

Hasil penelitian di lapangan terhadap satu orang Kepala Sekolah, delapan orang Guru IPS dan 20 orang siswa di SMP Negeri 2 Makassar, diperoleh tingkat kinerja guru IPS SMP sebagai berikut.

Tabel 6. Hasil Penilaian Kepala Sekolah, Guru dan Siswa terhadap Kinerja Guru IPS SMP Negeri 2 Makassar

\begin{tabular}{lcccc}
\hline Aspek yang & \multicolumn{3}{c}{ Penilai } & Rerata \\
\cline { 2 - 4 } \multicolumn{1}{c}{ Dinilai } & Kepsek & Guru & Siswa & Skor \\
\hline Perencanaa & 4,29 & 4,27 & & 4,28 \\
Pelaksanaan & 4,08 & 4,19 & 3,31 & 3,86 \\
Penilaian & 4,43 & 4,18 & 3,76 & 4,12 \\
\hline Rerata Skor & 4,27 & 4,21 & 3,53 & 4,00 \\
\hline
\end{tabular}

Tabel 6 menunjukkan bahwa hasil penilaian yang dilakukan oleh Kepala Sekolah, Guru dan Siswa memiliki rerata skor 4,00. Nilai tersebut masuk dalam kategori "Baik" karena berada di antara nilai 3,414,20 . Rerata skor penilaian yang dilakukan oleh kepala sekolah terhadap kinerja guru IPS sebesar 4,27 atau pada kategori "Sangat Baik" karena nilai yang diperoleh lebih besar dari 4,20 . Rerata skor penilaian yang dilakukan oleh guru IPS terhadap kinerjanya sebesar 4,21 atau pada kategori "Sangat Baik" karena nilai yang diperoleh lebih besar dari 4,20. Rerata skor penilaian yang dilakukan oleh siswa terhadap kinerja guru IPS sebesar 3,53 
atau pada kategori "Baik" karena berada di antara nilai 3,41-4,20. Kinerja guru dikatakan baik karena berdasarkan penilaian kepala sekolah, guru dan siswa secara keseluruhan perencanaan pembelajaran, pelaksanaan dan penilaian pembelajaran telah dilaksanakan dengan baik, serta mendapat skor rerata lebih dari 3,41 di mana nilai tersebut termasuk dalam kategori baik.

Jika dilihat dari tiap aspek, rerata skor pada perencanaan pembelajaran sebesar 4,28 atau pada kategori "Sangat Baik" karena nilai yang diperoleh lebih besar dari 4,20. Hal tersebut menunjukkan bahwa pada aspek perencanaan pembelajaran ini guru memiliki kinerja yang sangat baik. Guru memiliki kemampuan dalam pengembangan silabus dengan sangat baik. Guru memiliki kemampuan penyusunan rencana pelaksanaan pembelajaran dengan sangat baik. Rerata skor pada aspek pelaksanaan pembelajaran sebesar 3,86 atau pada kategori "Baik" karena berada di antara nilai 3,41-4,20. Kinerja guru pada aspek pelaksanaan pembelajaran dikatakan baik karena secara keseluruhan guru telah dapat mengelola kelas dengan baik, memanfaatkan media dan sumber belajar secara efektif, serta menerapkan metode pembelajaran sesuai dengan standar kompetensi, kompetensi dasar dan indikator yang harus dimiliki siswa. Rerata skor pada aspek penilaian pembelajaran sebesar 4,12 atau pada kategori "Baik" karena berada di antara nilai 3,41-4,20. Kinerja guru pada aspek penilaian pembelajaran dikatakan baik karena secara keseluruhan guru telah menerapkan berbagai teknik penilaian yang efektif, melakukan penilaian secara objektif dan adil, serta memberikan feedback terhadap tugas-tugas yang dikerjakan siswa. Dengan demikian, dapat disimpulkan bahwa guru IPS di SMP Negeri 2 Makassar memiliki kinerja baik.

\section{Penilaian Kinerja Guru IPS di SMP N 13 Makassar}

Hasil penelitian di lapangan terhadap satu orang Kepala Sekolah, enam orang Guru IPS dan 36 orang siswa di SMP Negeri 13 Makassar, diperoleh tingkat kinerja guru IPS SMP disajikan pada Tabel 7.

Tabel 7 menunjukkan bahwa hasil penilaian yang dilakukan oleh Kepala Sekolah, Guru dan Siswa memiliki rerata skor sebesar 4,36. Nilai tersebut masuk dalam kate- gori "Sangat Baik" karena nilai yang diperoleh lebih besar dari 4,20. Rerata skor penilaian yang dilakukan oleh kepala sekolah terhadap kinerja guru IPS sebesar 4,47 atau "Sangat Baik" karena nilai yang diperoleh lebih besar dari 4,20. Rerata skor penilaian yang dilakukan oleh guru IPS terhadap kinerjanya sebesar 4,43 atau "Sangat Baik" karena nilai yang diperoleh lebih besar dari 4,20. Rerata skor penilaian yang dilakukan oleh siswa terhadap kinerja guru IPS sebesar 4,20 atau "Baik" karena berada di antara nilai 3,414,20. Kinerja guru dikatakan sangat baik karena berdasarkan penilaian kepala sekolah, guru dan siswa secara keseluruhan perencanaan pembelajaran, pelaksanaan dan penilaian pembelajaran telah dilaksanakan dengan sangat baik, serta mendapat skor rerata lebih dari 4,20 di mana nilai tersebut termasuk dalam kategori sangat baik.

Tabel 7. Hasil Penilaian Kepala Sekolah, Guru dan Siswa terhadap Kinerja Guru IPS SMP Negeri 13 Makassar

\begin{tabular}{lcccc}
\hline \multirow{2}{*}{$\begin{array}{c}\text { Aspek yang } \\
\text { Dinilai }\end{array}$} & \multicolumn{3}{c}{ Penilai } & $\begin{array}{c}\text { Rerata } \\
\text { Skor }\end{array}$ \\
\cline { 2 - 4 } & Kepsek & Guru & Siswa & 4,42 \\
\hline Perencanaa & 4,14 & 4,69 & & 4,30 \\
Pelaksanaan & 4,50 & 4,31 & 4,10 & 4,30 \\
Penilaian & 4,86 & 4,24 & 4,27 & 4,46 \\
\hline Rerata Skor & 4,47 & 4,43 & 4,20 & 4,36 \\
\hline
\end{tabular}

Jika dilihat dari tiap aspek, rerata skor pada perencanaan pembelajaran sebesar 4,42 atau pada kategori "Sangat Baik" karena nilai yang diperoleh lebih besar dari 4,20. Kinerja guru pada aspek perencanaan pembelajaran dikatakan sangat baik karena secara keseluruhan guru telah dapat mengembangkan silabus dan menyusun RPP dengan sangat baik serta sesuai dengan standar kompetensi, kompetensi dasar dan indikator yang harus dimiliki siswa pada kurikulum yang diacu. Rerata skor pada aspek pelaksanaan pembelajaran sebesar 4,30 atau pada kategori "Sangat Baik" karena nilai yang diperoleh lebih besar dari 4,20. Kinerja guru pada aspek pelaksanaan pembelajaran dikatakan sangat baik karena secara keseluruhan guru telah memiliki kemampuan dalam pengelolaan kelas dengan sangat baik, guru memiliki kemampuan dalam menggunakan media dan sumber belajar secara efektif, serta guru memiliki kemampuan dalam menerapkan metode pembelajaran yang 
bervariasi serta sesuai dengan standar kompetensi, kompetensi dasar dan indikator yang harus dimiliki siswa.

Rerata skor pada aspek penilaian pembelajaran sebesar 4,46 atau pada kategori "Sangat Baik" karena nilai yang diperoleh lebih besar dari 4,20. Kinerja guru pada aspek penilaian pembelajaran dikatakan sangat baik karena secara keseluruhan guru memiliki kemampuan dalam menerapkan teknik penilaian yang variatif dalam pembelajarannya, baik tertulis maupun lisan, guru memiliki kemampuan menilai hasil belajar siswa dengan objektif dan adil, serta bahwa guru sering memberikan feedback terhadap tugas-tugas yang dikerjakan siswa. Dengan demikian, dapat disimpulkan bahwa guru IPS di SMP Negeri 13 Makassar memiliki kinerja yang sangat baik.

\section{Penilaian Kinerja Guru IPS di SMP N 8 Makassar}

Hasil penelitian di lapangan terhadap satu orang Kepala Sekolah, enam orang Guru IPS dan 19 orang siswa di SMP Negeri 8 Makassar, diperoleh tingkat kinerja guru IPS SMP disajikan pada Tabel 8 .

Tabel 8. Hasil Penilaian Kepala Sekolah, Guru dan Siswa terhadap Kinerja Guru IPS SMP Negeri 8 Makassar

\begin{tabular}{|c|c|c|c|c|}
\hline \multirow{2}{*}{$\begin{array}{c}\text { Aspek yang } \\
\text { Dinilai }\end{array}$} & \multicolumn{3}{|c|}{ Penilai } & \multirow{2}{*}{$\begin{array}{c}\text { Rerata } \\
\text { Skor }\end{array}$} \\
\hline & Kepsek & Guru & Siswa & \\
\hline Perencanaa & 3,57 & 4,43 & & 4,00 \\
\hline Pelaksanaan & 3,83 & 4,30 & 3,72 & 3,95 \\
\hline Penilaian & 4,00 & 4,46 & 4,12 & 4,19 \\
\hline Rerata Skor & 3,80 & 4,40 & 3,92 & 4,04 \\
\hline
\end{tabular}

Tabel 8 menunjukkan bahwa hasil penilaian yang dilakukan oleh Kepala Sekolah, Guru dan Siswa memiliki rerata skor sebesar 4,04. Nilai tersebut masuk dalam kategori "Baik" karena nilai yang diperoleh berada di antara 3,41-4,20. Rerata skor penilaian yang dilakukan oleh kepala sekolah terhadap kinerja guru IPS sebesar 3,80 atau pada kategori "Baik" karena nilai yang diperoleh berada di antara 3,41-4,20. Rerata skor penilaian yang dilakukan oleh guru IPS terhadap kinerjanya sebesar 4,40 atau pada kategori "Sangat Baik" karena nilai yang diperoleh lebih besar dari 4,20. Rerata skor penilaian yang dilakukan oleh siswa terhadap kinerja guru IPS sebesar 3,92 atau pada kategori "Baik" karena berada di antara nilai 3,414,20. Kinerja guru dikatakan baik karena berdasarkan penilaian kepala sekolah, guru dan siswa secara keseluruhan perencanaan pembelajaran, pelaksanaan dan penilaian pembelajaran telah dilaksanakan dengan baik.

Jika dilihat dari tiap aspek, rerata skor pada perencanaan pembelajaran sebesar 4,00 atau pada kategori "Baik" karena nilai yang diperoleh berada di antara 3,41-4,20. Kinerja guru pada aspek perencanaan pembelajaran dikatakan baik karena secara keseluruhan guru telah dapat mengembangkan silabus dan menyusun RPP dengan baik serta sesuai dengan standar kompetensi, kompetensi dasar dan indikator yang harus dimiliki siswa. Rerata skor pada aspek pelaksanaan pembelajaran sebesar 3,95 atau pada kategori "Baik" karena nilai yang diperoleh berada di antara 3,41-4,20. Kinerja guru pada aspek pelaksanaan pembelajaran dikatakan baik karena secara keseluruhan guru telah dapat mengelola kelas dengan baik, memanfaatkan media dan sumber belajar secara efektif, serta menerapkan metode pembelajaran sesuai dengan standar kompetensi, kompetensi dasar dan indikator yang harus dimiliki siswa. Rerata skor pada aspek penilaian pembelajaran sebesar 4,19 atau pada kategori "Baik" karena nilai yang diperoleh lebih besar dari 3,41-4,20. Kinerja guru pada aspek penilaian pembelajaran dikatakan baik karena secara keseluruhan guru telah menerapkan berbagai teknik penilaian yang efektif, melakukan penilaian secara objektif dan adil, serta memberikan feedback terhadap tugas-tugas yang dikerja-kan siswa. Dengan demikian, dapat disimpul-kan bahwa guru IPS di SMP Negeri 8 Makassar memiliki kinerja yang baik.

Berdasarkan data yang diperoleh, diketahui guru IPS yang menjadi responden dalam penelitian ini telah bersertifikasi pendidik paling lama sejak tahun 2007 dan ada pula yang bersertifikasi pendidik tahun 2013, sehingga jika terhitung sampai saat ini, guru IPS telah bersertifikasi pendidik antara tiga hingga sembilan tahun. Data lama sertifikasi guru IPS dapat dilihat pada Tabel 9.

Tabel 9 menunjukkan data yang diperoleh dari guru pascasertifikasi lima tahun kurang dan pascasertifikasi lebih dari lima tahun. Berdasarkan data yang tersebut, dapat dilakukan analisis uji beda terhadap kinerja 
guru IPS berdasarkan lama sertifikasinya, yaitu menggunakan uji beda independent $t$ test. Uji ini dilakukan dengan membandingkan kinerja guru IPS pasca sertifikasi lebih dari lima tahun dengan kinerja guru IPS pasca sertifikasi lima tahun atau kurang dari itu. Hasil uji beda independent t test disajikan dalam Tabel berikut.

Tabel 9. Data Lama Sertifikasi dan Kinerja Guru IPS

\begin{tabular}{ccc}
\hline \multirow{2}{*}{ No } & \multicolumn{2}{c}{ Kinerja Guru } \\
\cline { 2 - 3 } & $\leq 5$ tahun & $>5$ tahun \\
\hline 1 & 3,03 & 4,13 \\
2 & 3,93 & 4,69 \\
3 & 4,61 & 4,09 \\
4 & 4,39 & 3,93 \\
5 & 4,17 & 4,61 \\
6 & 4,28 & 4,51 \\
7 & 4,33 & 4,28 \\
8 & 4,15 & 3,97 \\
9 & 4,08 & 4,56 \\
10 & 4,23 & 4,42 \\
11 & 4,32 & 4,63 \\
12 & 4,21 & 4,65 \\
13 & 4,72 & 4,28 \\
14 & & 3,67 \\
\hline
\end{tabular}

Tabel 10. Uji Independet T Test Kinerja Guru IPS Pascasertifikasi Berdasarkan Lama Sertifikasi

\begin{tabular}{lccc}
\hline & $\begin{array}{c}\text { Levene's } \\
\text { Test }\end{array}$ & t hitung & Sig \\
\hline $\begin{array}{l}\text { Kinerja Guru } \\
\text { Pascasertifikasi }\end{array}$ & 0,817 & $-0,911$ & 0,371 \\
\hline
\end{tabular}

Tabel 10 menunjukkan ada tidaknya perbedaan kinerja guru IPS pascasertifikasi berdasarkan lama sertifikasi. Hasil penelitian menunjukkan bahwa nilai Levene's test yang diperoleh sebesar 0,817 , nilai tersebut lebih besar dari 0,05 . Artinya, data yang terkumpul bersifat homogen atau memiliki karakteristik yang sama. Nilai thitung yang diperoleh sebesar $-0,911$, nilai tersebut lebih kecil dibanding dengan nilai t tabel, yaitu 2,060. Selain itu, nilai signifikansi yang diperoleh sebesar 0,371 , di mana nilai tersebut jauh lebih besar dari 0,05. Dengan demikian dapat disimpulkan bahwa kinerja guru IPS tingkat SMP di Kota Makassar berdasarkan lama sertifikasi lebih dari lima tahun dengan lima tahun kurang secara signifikan tidak ada bedanya.
Hal tersebut menunjukkan bahwa kinerja guru IPS tingkat SMP di Kota Makassar pasca sertifikasi berdasarkan tidak mengalami peningkatan setelah lima tahun sertifikasi.

\section{Simpulan}

Berdasarkan hasil penelitian dan pembahasan, maka dapat disimpulkan bahwa:

Guru IPS tingkat SMP pascasertifikasi di Kota Makassar memiliki kinerja yang baik dilihat dari aspek perencanaan pembelajaran, yang ditunjukkan dengan nilai rerata sebesar 4,04. Rerata penilaian yang diberikan oleh kepala sekolah mengenai kinerja guru secara keseluruhan sebesar 3,67 atau pada kategori baik. Rerata penilaian diri secara keseluruhan sebesar 4,42 atau pada kategori sangat baik.

Guru IPS tingkat SMP pascasertifikasi di Kota Makassar memiliki kinerja yang baik dilihat dari aspek pelaksanaan pembelajaran, yang ditunjukkan dengan nilai rerata sebesar 3,77. Rerata penilaian yang diberikan oleh kepala sekolah mengenai kinerja guru secara keseluruhan sebesar 3,60 atau pada kategori baik. Rerata penilaian diri secara keseluruhan sebesar 4,16 atau pada kategori baik. Rerata penilaian yang diberikan oleh siswa mengenai kinerja guru secara keseluruhan sebesar 3,56 atau pada kategori baik.

Guru IPS tingkat SMP pascasertifikasi di Kota Makassar memiliki kinerja yang baik dilihat dari aspek penilaian pembelajaran, yang ditunjukkan dengan nilai rerata sebesar 3,96. Rerata penilaian yang diberikan oleh kepala sekolah mengenai kinerja guru secara keseluruhan sebesar 3,60 atau pada kategori baik. Rerata penilaian diri secara keseluruhan sebesar 4,16 atau pada kategori baik. Rerata penilaian yang diberikan oleh siswa mengenai kinerja guru secara keseluruhan sebesar 3,56 atau pada kategori baik.

Penelitian ini menemukan bahwa kinerja guru IPS pascasertifikasi lima tahun dan yang kurang dari lima tahum secara signifikansi tidak memiliki perbedaan. Hal tersebut menunjukkan bahwa pascasertifikasi guru tidak mengalami peningkatan dalam kinerjanya.

Berdasarkan hasil penelitian dan simpulan tersebut, maka saran yang dapat direkomendasikan sebagai berikut:

Pihak sekolah sebaiknya melakukan evaluasi secara rutin untuk mengetahui apa 
yang menjadi kekuatan dan kelemahan guru dalam mengajar. Dengan demikian yang menjadi kekuatannya dapat terus dipertahankan, sedang kelemahannya dapat segera diperbaiki.

Pihak Dinas Pendidikan sebaiknya menyelenggarakan pelatihan dan pendidikan secara rutin untuk guru-guru IPS tingkat SMP, khususnya guru bersertifikasi pendidik, sehingga guru dapat mengembangkan kemampuannya dalam menggunakan dan memanfaatkan berbagai media/sarana belajar yang tersedia di lingkungan sekolah secara maksimal.

Bagi guru sebaiknya untuk terus mengembangkan kemampuannya dalam mengajar maupun dalam mengembangkan media/ sumber belajar, sehingga kegiatan pembelajaran yang dilakukan menjadi lebih menarik bagi siswa dan tidak membosankan dan mudah dipahami oleh siswa.

\section{Daftar Pustaka}

Araujo, A. M. P. de, \& Slomski, V. G. (2013). Active learning methods-An analysis of applications and experiences in Brazilian accounting teaching. Creative Education, 4(12), 20-27. https://doi.org/10.4236/ce.2013.412A20 04

Arikunto, S. (2010). Prosedur penelitian: suatu pendekatan praktik. Jakarta: Rineka Cipta.

Boyd, D., Goldhaber, D. D., Lankford, H., \& Wyckoff, J. H. (2007). The Effect of Certification and Preparation on Teacher Quality. The Future of Children, 17(1), 45-68. https://doi.org/10.1353/foc.2007.0000

Carpenter, J. M. (2006). Effective teaching methods for large classes. Journal of Family \& Consumer Sciences Education, 24(2). Retrieved from http://www.natefacs.org/Pages/v24no2/v 24no2Carpenter.pdf

Dariyanto, E. (2015). PGRI ingatkan pemerintah agar tuntaskan amanat UU guru dan dosen. Retrieved June 22, 2017, from http://news.detik.com/berita/2943974/pg ri-ingatkan-pemerintah-agar-tuntaskanamanat-uu-guru-dan-dosen
Darling-Hammond, L. (2010). How teacher performance assessments can measure and improve teaching.

Americanprogress.org: Center for American Progress.

Darling-Hammond, L., \& Youngs, P. (2002). Defining "Highly Qualified Teachers": What Does "Scientifically-Based Research" Actually Tell Us? Educational Researcher, 31(9), 13-25. Retrieved from http://www.jstor.org/stable/3594491

Depdiknas. Undang-Undang No. 14 Tahun 2005 tentang Guru dan Dosen (2005). Jakarta.

Direktorat Jenderal Pendidikan Islam Kemenag RI. (2011). Guru layak mengajar masih minim. Retrieved from http://pendis.kemenag.go.id/index.php?a =detilberita\&id=5982\#. VYum5_DnHeh

Direktorat Tenaga Kependidikan. (2008). Penilaian kinerja guru. Jakarta: Direktorat Jendral Peningkatan Mutu Pendidikan dan Tenaga Kependidikan Departemen Pendidikan Nasional.

Elliott, K. (2015). Teacher performance appraisal: more about performance or development? Australian Journal of Teacher Education, 40(40), 102-116. https://doi.org/10.14221/ajte.2015v40n9. 6

Gallant, A., \& Mayer, D. (2012). Teacher performance assessment in teacher education: an example in Malaysia. Journal of Education for Teaching, 38(3), 295-307. https://doi.org/10.1080/02607476.2012.6 68330

Indrawati, N. K. S. (2013). Pengaruh masa kerja terhadap kompetensi pedagogik guru IPS SMP Negeri Singaraja tahun ajaran 2011/2012. Jurnal Jurusan Pendidikan Ekonomi, 1(1). Retrieved from https://ejournal.undiksha.ac.id/index.php /JJPE/article/view/399

Ingweson, D. W. (2000). Classroom management a california resource guide. Downey: Country Office of Education. 
Kemdikbud. (2015). Panduan penilaian untuk sekolah menengah pertama (SMP). Jakarta: Kementerian Pendidikan dan Kebudayaan, Direktorat Pembinaan Sekolah Menengah Pertama, Direktorat Jenderah Pendidikan Dasar dan Menengah.

Ningsih, N. P. R. A. (2013). Studi komparatif kinerja guru bersertifikat pendidik dan yang belum dalam pengelolaan pembelajaran di SMPN3 Singaraja. Jurnal Jurusan Pendidikan Ekonomi, 1(1). Retrieved from https://ejournal.undiksha.ac.id/index.php /JJPE/article/view/479

Ontario. (2010). Teacher performance appraisal: technical requirements manual. Ontario: Ministry of Education.

Pecheone, R. L., \& Chung, R. R. (2006). Evidence in teacher education. Journal of Teacher Education, 57(1), 22-36. https://doi.org/10.1177/00224871052840 45

Rahayu, T. (2015). Antara Guru, Siswa, Media dan metode pembelajaran. Retrieved October 10, 2015, from http://www.kompasiana.com/tryrahayu/a ntara-guru-siswa-media-dan-metodepembelajaran_55301cda6ea834aa2b8b4 $57 \mathrm{f}$

Rusman. (2013). Seri manajemen sekolah bermutu: model-model pembelajaran mengembangkan profesionalisme guru. Jakarta: Raja Grafindo Persada.
Sugiyono. (2011). Metode penelitian kuantitatif, kualitatif dan $R \& D$. Bandung: Alfabeta.

Suryarahman, E., \& Hastuti, H. (2014). Kinerja guru IPS SMP bersertifikasi profesi berdasarkan standar kompetensi guru di Kabupaten Lombok Utara. Harmoni Sosial: Jurnal Pendidikan IPS, 1(2). https://doi.org/10.21831/HSJPI.V1I2.24 35

Taras, M. (2005). Assessment - summative and formative - Some theoretical reflections. British Journal of Educational Studies, 53(4), 466-478. https://doi.org/10.1111/j.14678527.2005.00307.x

Wahyudi, K. . E., Supranoto, \& Suji. (2012). Measuring Performance of Teacher Certification Program. International Journal of Administrative Science \& Organization, 19(3), 153-161.

Widoyoko, S. E. P. (2009). Teknik Penyusunan Instrumen Penelitian. Yogyakarta: Pustaka Pelajar.

William, D. (2012). Assessment: the bridge between teaching and learning. Voices from the Middle, 21(2).

Yusran, A. (2013). Kualitas pendidikan di Makassar bobrok. Retrieved June 25, 2017, from http://kabarindonesia.com/berita.php?pil $=26 \& j \mathrm{~d}=$ Kualitas + Pendidikan + di + Maka ssar+Bobrok\&dn=20130405084607 